\title{
An Outbreak of Winter Dysentery Caused by Bovine Coronavirus in a High-Production Dairy Cattle Herd from a Tropical Country
}

\author{
Elisabete Takiuchi, Aline Fernandes Barry, Alice Fernandes Alfieri, Patrícia Filippsen and \\ Amauri Alcindo Alfieri ${ }^{*}$ \\ Laboratório de Virologia Animal; Departamento de Medicina Veterinária Preventiva; Universidade Estadual de \\ Londrina; C. P.: 6001; 86051-990; Londrina - PR - Brasil
}

\begin{abstract}
Bovine coronavirus (BCoV) is a known cause of winter dysentery (WD) in adult cattle. The morbidity of the disease is high, that results in a significant decrease in milk production and consequently, economic losses. In the present study, we report on a classical outbreak of WD that affected a high-production Holstein dairy herd raised in a tropical country. The lactating batch included 154 cows, and 138 (90\%) presented diarrhea in a short (nine days) period of time. Three (2\%) cows died. The other batches of animals did not become ill. The evolution of the disease in the herd, including the clinical signs and epidemiological features, strongly suggested a WD case. Semi-nested PCR and RFLP confirmed that BCoV was the cause of the infection. Samples tested negative for all other enteric pathogens. This case report highlights the importance of BCoV in WD even in tropical countries such as Brazil.
\end{abstract}

Key words: cattle, dairy herd, winter dysentery, diarrhea, bovine coronavirus

\section{INTRODUCTION}

Bovine coronavirus $(\mathrm{BCoV})$ is a member of the Coronaviridae family that infects young and adult cattle. In newborn calves, the virus can cause severe diarrhea. In adult cattle, the outbreaks of enteric disease caused by $\mathrm{BCoV}$ infection are called winter dysentery (WD). Economic losses are the primary concern of newborn or adult $\mathrm{BCoV}$ infection, as the morbidity rates are high and may reach up to $100 \%$ of the herd. BCoV also infects the respiratory tract of calves and feedlot cattle (Saif and Heckert; 1990; Traven et al., 2001; Stipp et al., 2009).
WD is an acute diarrheic disease that is characterized by a sudden onset of dark, watery, often bloody diarrhea, which is accompanied by variable depression and anorexia in adult beef and dairy cattle. The outbreaks occur during the winter season and result in high morbidity and low mortality rates. In an affected cattle herd, milk production may not return to normal for several weeks or even during that lactation period, resulting in significant economic losses for the milk industry (Macpherson, 1957; Saif et al., 1988; Jactel et al., 1990; Traven et al., 2001).

$\mathrm{BCoV}$ is an enveloped virus and its environmental viability is not favored by high intensity ultraviolet

\footnotetext{
*Author for correspondence: alfieri@uel.br
} 
(UV) light, which is present during the warmer seasons (Saif and Heckert; 1990). It has recently been demonstrated that $\mathrm{BCoVs}$ also circulate during the warmer seasons, but there are genetic differences between the warm-season and winterseason strains, which reflects on the ability of the virus to cause disease (Park et al., 2006). However, cattle are more efficiently infected in the winter, which increases the environmental contamination and justifies the high morbidity of WD during the cold months (Clark, 1993).

Although tropical countries do not have the welldefined seasons of countries in the northern hemisphere, some counties in the southern region of Brazil have low temperatures and low UV light intensity during the winter. Under these conditions, the viral load of $\mathrm{BCoV}$ in the environment increases, and a higher number of cattle may be exposed to $\mathrm{BCoV}$ (Collins et al., 1987).

The association between exposure to $\mathrm{BCoV}$ and outbreaks of WD in dairy herds has been frequently reported in the United States, Europe, Japan, and Canada (Traven et al., 1993; Millane et al., 1995; Fukutomi et al., 1999; Cho et al., 2000). However, reports of $\mathrm{BCoV}$-induced WD in dairy herds from tropical areas (e.g., South America) are still sporadic (Brandão et al., 2002; 2007). This study reports on a WD outbreak with three fatal outcomes in a high-production dairy herd from a Brazilian county, which occurred during the winter.

\section{MATERIALS AND METHODS}

\section{Dairy herd}

An outbreak of diarrhea occurred in a dairy herd of 154 lactating cows during June of 2005. The cows were from a farm in Ponta Grossa city, Paraná state, South Region of Brazil. The cows were black and white high-production Holsteins with adequate body condition scores, raised under freestall management.

\section{Outbreak}

Three lactating cows presented with mild diarrhea and were placed together. Two days later, the disease quickly spread to twenty more animals that were in adjacent areas. Six days later, ninety percent of the cows were affected, and most cows developed progressive bloody and watery diarrhea that lasted three to four days before fecal consistency returned to normal. In summary, of the 154 lactating cows, 138 were affected over a period of 9 days. Three of the affected cows died. No pre-partum cows, dry cows, heifers, or calves become ill.

The average of milk production under normal conditions was 37 liters/cow/day, but it dropped during the outbreak to 26 liters/cow/day.

\section{Fecal samples}

One of the cows with watery diarrhea that died during the outbreak was necropsied by the assisting veterinarian. A stool sample with undigested blood and a putrid smell was collected directly from the large intestine of this cow. The sample was tested for Clostridium spp, enterotoxigenic E. coli, Eimeria spp, Cryptosporidium spp, bovine rotavirus groups A, $\mathrm{B}$, and $\mathrm{C}$, and bovine viral diarrhea virus (BVDV) by bacteriological/parasitological routine tests, modified Ziehl-Nielsen method, polyacrylamide gel electrophoresis, and RT-PCR, respectively (Gouvea et al., 1991; Alfieri et al., 1999; 2006; Lunardi et al., 2008).

\section{Nucleic acid extraction}

Semi-nested PCR was used to test for BCoV. Fecal suspensions were prepared as $20 \%(\mathrm{v} / \mathrm{v})$ liquid feces in PBS and centrifuged at $3,000 \mathrm{x} \mathrm{g}$ for $20 \mathrm{~min}$. The supernatant was used for nucleic acid extraction, which was performed using a combination of the phenol/chloroform/isoamyl alcohol and silica/guanidine isothiocyanate methods, according to Alfieri et al. (2006).

\section{Semi-nested PCR}

The reverse transcription (RT) reaction was performed with $\mathrm{BCoV} 2$ anti-sense (5' TGTGGGTGCGAGTTCTGC 3') primer. PCR and the semi-nested assay were performed according Takiuchi et al. (2006) with primers BCoV1 sense (5' CGATGAGGCTATTCCGAC $\left.3^{\prime}\right)$ and $\mathrm{BCoV} 2$ anti-sense for the first round, and BCoV3 sense (5' TTGCTAGTCTTGTTCTGGC $\left.3^{\prime}\right)$ and $\mathrm{BCoV} 2$ anti-sense, respectively. These primers were designed from the highly conserved region of the Mebus strain N gene (GenBank accession number U00735) with a predicted product of $251 \mathrm{bp}$. The products were analyzed by electrophoresis in a $2 \%$ agarose gel in TBE buffer, stained with ethidium bromide, and visualized under UV light. 


\section{RFLP}

To confirm the result of the semi-nested PCR assay, restriction fragment length polymorphism (RFLP) of the BCoV-amplified product was carried out using the Hae III enzyme (Invitrogen ${ }^{\mathrm{TM}}$ Life Technologies, USA). The reaction was performed following the manufacturer's instructions.

\section{RESULTS AND DISCUSSION}

A 251 bp fragment was amplified from the diarrheic fecal sample analyzed using semi-nested PCR specific for BCoV. The result of the seminested PCR was confirmed by RFLP with the Hae III enzyme, yielding fragments of 88 and $163 \mathrm{bp}$ from the $\mathrm{BCoV} 251 \mathrm{bp}$ amplicon. All tests for other enteropathogens were negative.

An outbreak of bloody and watery diarrhea that exclusively affected lactating cows was reported. Several factors can act alone or together to cause an enteric disease, including environmental, managemental, nutritional, and infectious agents. The progression in which the clinical manifestation spread into the herd strongly suggested that an infectious agent was involved in the disease etiology. Three cows became ill on the first day, and 90\% (138/154) of the herd was diarrheic by the ninth day. Virus replication in the hosts during infection resulted in the excretion of high viral titers, which increased the viral load in the environment and exposed the whole herd. The presence of the receptor-destroying enzyme (RDE), which might be present in circulating strains in the cold months, enhances the virulence of $\mathrm{BCoV}$ by facilitating the elution of mature virions from the surfaces of infected cells and more effectively disseminating the virus (Park et al., 2006).

The etiological agent responsible for the outbreak infected both the small and large intestines, as blood was present in feces of diarrheic cows; this excludes a large range of enteric pathogens, which are restricted to the duodenum and jejunum (Saif and Heckert; 1990). The presence of $\mathrm{BCoV}$ was confirmed using semi-nested PCR and RFLP on a stool sample that was collected from a necropsied cow. Although these results and the typical clinical presentation that strongly suggested a WD outbreak, the fecal sample was also analyzed for other enteric pathogens, including infectious agents that most commonly infect younger animals, such as E. coli, Cryptosporidium spp., and BVDV. However, all tests were negative, leaving $\mathrm{BCoV}$ as the only possible source of infection. Smith et al. (1998) demonstrated that a recent herd exposure to $\mathrm{BCoV}$ as well as certain housing and management practices may have increased the risk of a WD outbreak in Ohio/USA. Some WD outbreaks might be associated with BVDV co-infection, which may aggravate the disease (Smith et al., 1998; Alenius et al., 1991). However, there was no association between BVDV infection and WD outbreak in this study.

Pre-partum cows and heifers were placed in another barn (stall) approximately 600 meters away and were not affected. Furthermore, the cows in these batches did not develop diarrhea, which may have been due to their lower production exploration. The lactating cows were both pregnant and in high milk production, while the other batches of cows were either not pregnant or both not pregnant and not producing milk. Neonatal calf diarrhea was not verified in the calves batch either.

In addition to the clinical signs of infection, decreases in milk production are also commonly described as a consequence of WD. The cows involved in the outbreak herein presented had a 30 percent drop in milk production that returned to normal two weeks later. Durham et al. (1989) previously described an outbreak with very similar clinical presentation and a 50\% drop in milk production.

Cow mortality is not a frequently reported result of WD outbreaks, and the economic losses are more often related to drops in milk production. In this case, three animals died as a consequence of the disease severity, but WD-induced mortality has previously been described, even with the addition of supportive therapy (Natsuaki et al., 2007). Genetic adaptation of the winter-circulating $\mathrm{BCoV}$ strains has also been reported (Park et al., 2006). The presence of strains that are more pathogenic could also be a determinant of disease morbidity and mortality.

While there are numerous reports that associate $\mathrm{BCoV}$ with WD outbreaks in North America, Asia, and Europe, there have been few reports in South America and more specifically in Brazil (Brandão et al., 2002; 2007). The present case was observed in Ponta Grossa city, Paraná State, Brazil. This region is situated in southern Brazil where the temperatures are normally lower than in the other Brazilian geographical areas. The 
outbreak occurred in the winter month of June, and the lower temperatures and UV light intensity, which are common in the winter, can result in increased virus stability in the environment and posterior dissemination among confined cattle.

This finding suggests that $\mathrm{BCoV}$-induced WD also occurs in tropical areas and should be considered in the etiology of diarrhea outbreaks in adult cattle in Brazil. The use of a sensitive and specific diagnostic technique (i.e., SN-PCR) described in this study has proven useful for $\mathrm{BCoV}$ detection in fecal samples from naturally-infected adult cows. This method enables the development of epidemiological studies of $\mathrm{BCoV}$-induced WD outbreaks in Brazil.

\section{ACKNOWLEDGEMENTS}

The financial resources for the conduction of this study were supported by the project BioAgroPar financed by FINEP, SETI/PR, and Fundação Araucária/PR; and by CNPq/Brazil.

Part of the research activities of this study was carried out in the Agricultural Research Support Laboratory (Laboratório de Apoio à Pesquisa Agropecuária - LAPA) / PROPPG / UEL.

Alfieri, A.A. and Alfieri, A.F. are recipients of CNPq fellowships.

\section{RESUMO}

$\mathrm{O}$ coronavirus bovino $(\mathrm{BCoV})$ pode causar a diarreia de inverno (WD - Winter Dysentery) ao infectar bovinos adultos, particularmente em regiões de clima temperado ou frio. A morbidade da doença é alta, resultando em queda na produção de leite e, consequentemente, perdas econômicas. No presente estudo, é descrito um surto clássico de WD acometendo um rebanho de bovinos leiteiros da raça Holandesa $\mathrm{PB}$, de alta produção, proveniente do estado do Paraná. O lote afetado era composto por 154 vacas em lactação, sendo que $138(90 \%)$ apresentaram diarreia em um curto (nove dias) período de tempo e $3(2 \%)$ vacas morreram em consequência da diarreia, desidratação e desequilíbrio eletrolítico. As outras categorias de animais do rebanho (bezerras, novilhas e vacas secas) não apresentaram sinal clínico. A evolução da doença clínica, assim como a epidemiologia da infecção sugeriu um quadro clássico de WD. O diagnóstico foi realizado por meio da identificação do $\mathrm{BCoV}$, pela técnica de semi-nested PCR e confirmação por RFLP, em amostra fecal de uma vaca que veio a óbito. A presença de outros patógenos entéricos também foi avaliada e apresentou resultados negativos. $\mathrm{O}$ surto de WD descrito na região sul do Brasil alerta para a possibilidade da ocorrência dessa virose também em países situados em regiões de clima tropical.

\section{REFERENCES}

Alenius, S., Niskanen, R., Juntti, N., Larsson, B. (1991), Bovine coronavirus as the causative agent of winter dysentery: serological evidence. Acta Vet Scand, 32, 163-170

Alfieri, A. A., Leite, J. P. G., Alfieri, A. F., Jiang, B., Glass, R. I., Gentsch, J. R. (1999), Detection of field isolates of human and animal group $\mathrm{C}$ rotavirus by reverse transcription-polymerase chain reaction and digoxigenin-labeled oligonucleotide probes. $J$ Virol Methods, 83, 35-43

Alfieri, A. A., Parazzi, M. E., Takiuchi, E., Médici, K. C., Alfieri, A. F. (2006), Frequency of group A rotavirus in diarrhoeic calves in Brazilian cattle herds, 1998-2002. Trop Anim Health Prod, 38, 521-526

Brandão, P. E., Birgel Jr., E. H., Gregori, F., Rosales, C. A. R., Ruiz, V. L. A., Jerez, J. A. (2002), Bovine coronavirus detection in adult cows in Brazil. Arq Inst Biol, 69, 103-104

Brandão, P. E., Villarreal, L. Y. B., Gregori, F., Souza, S. L. P., Lopes, M. A. E., Gomes, C. R., Sforsin, A. J., Sanches, A. A., Rosales, C. A. R., Richtzenhain, L. J., Ferreira, A. J. P., Jerez, J. A. (2007), On the etiology of an outbreak of winter dysentery in dairy cows in Brazil. Braz J Vet Res, 27, 398-402

Cho, K. O., Halbur, P. G., Bruna, J. D., Sorden, S. D., Yoon, K. J., Janke, B. H., Chang, K. O., Saif, L. J. (2000), Detection and isolation of coronavirus from feces of three herds of feedlot cattle during outbreaks of winter dysentery-like disease. J Am Vet Med Assoc, 217, 1191-1194

Clark, M. A. (1993), Bovine coronavirus. Br Vet J, 149, 51-70

Collins, J. K., Riegel, C. A., Olson, J. D., Fountain, A. (1987), Shedding of enteric coronavirus in adult cattle. Am J Vet Res, 48, 361-365

Durham, P. J. K., Hassard, L. E., Armstrong, K. R., Naylor, J. M. (1989), Coronavirus-associated diarrhea (winter dysentery) in adult cattle, Can Vet J, 30, 825827

Fukutomi, T., Tsunemitsu, H., Akashi, H. (1999), Detection of bovine coronavirus from adult cows with epizootic diarrhea and their antigenic and biological diversities. Arch Virol, 144, 997-1006 
Gouvea, V., Allen, J. R., Glass, R. I., Fang, Z. Y., Bremont, M., Cohen, J., McCrae, M. A., Saif, L. J., Sinarachatanant, P., Caul, O. (1991), Detection of Group B and C Rotaviruses by Polymerase Chain Reaction. J Clin Microbiol, 29, 519-523

Jactel, B., Espinasse, J., Viso, M., Valiergue, H. (1990), An epidemiological study of winter dysentery in fifteen herds in France. Vet Res Commun, 14, 367

Lunardi, M., Headley, S. A., Lisbôa, J. A. N., Amude A. M., Alfieri, A. A. (2008), Outbreak of acute bovine viral diarrhea in Brazilian beef cattle: Clinicopathological findings and molecular characterization of a wild-type BVDV strain subtype 1b. Res Vet Sci, 85, 599-604

Macpherson, L. W. (1957), Bovine virus enteritis (winter dysentery). Can J Comp Med, 21, 184-192

Millane, G., Michaud, L., Dea, S. (1995), Biological and molecular differentiation between coronaviruses associated with neonatal calf diarrhoea and winter dysentery in adult cattle. Adv Exp Med Biol, 380, 2933

Natsuaki, S., Goto, K., Nakamura, K., Yamada, M., Ueo, H., Komori, T., Shirakawa, H., Uchinuno, Y. (2007), Fatal Winter Dysentery with Severe Anemia in An Adult Cow. J Vet Med Sci, 69, 957-960

Park, S. J., Jeong, C., Yoon, S. S., Choy, H. E., Saif, L. J., Park, S. H., Kim, Y. J., Jeong, J. H., Park, S. I., Kim, H. H., Lee, B. J., Cho, H. S., Kim, S. K., Kang, M. I., Cho, K. O. (2006), Detection and Characterization of Bovine Coronaviruses in Fecal Specimens of Adult Cattle with Diarrhea during the Warmer Seasons. J Clin Microbiol, 44, 3178-3188

Saif, L. J., Redman, D. R., Brock, K. V., Kohler, E. M., Heckert, R. A. (1988), Winter dysentery in adult dairy cattle: Detection of coronavirus in the feces. Vet Rec, 123, 300-301
Saif, L. J., Heckert, R. (1990), Enteropathogenic coronaviruses, In-L. J. Saif and K. W. Theil. (ed.), Viral diarrheas of man and animals. CRC Press, Boca Raton, Florida. pp. 185-252

Smith, D. R., Fedorka-Cray, P. J., Mohan, R., Brock, K. V., Wittum, T. E., Morley, P. S., Hoblet, K. H., Saif, L. J. (1998), Epidemiologic herd-level assessment of causative agents and risk factors for winter dysentery in dairy cattle. Am J Vet Res, 59, 994-1001

Stipp, D. T., Barry, A. F., Alfieri, A. F., Takiuchi, E., Amude, A. M., Alfieri, A. A. (2009), Frequency of $\mathrm{BCoV}$ detection by a semi-nested PCR assay in faeces of calves from Brazilian cattle herds. Trop Anim Health Prod, in press. doi: 10.1007/s11250009-9347-2

Takiuchi, E., Stipp, D. T., Alfieri, A. F., Alfieri A. A. (2006), Improved detection of bovine coronavirus $\mathrm{N}$ gene in faeces of calves infected naturally by a seminested PCR assay and an internal control. J Virol Methods, 131, 148-154

Traven, M., Sundberg, J., Larsson, B., Niskanen, R. (1993), Winter dysentery diagnosed by farmers in dairy herds in central Sweden: incidence, clinical signs and protective immunity. Vet Rec, 133, 315-318

Traven, M., Naslund, K., Linde, N., Linde, B., Silvan, A., Fossum, C., Hedlund, K. O., Larsson, B. (2001), Experimental reproduction of winter dysentery in lactating cows using BCV-comparison with BCV infection in milk-fed calves. Vet Microbiol, 81, 127151 
PAGINA
EM
BRANCO 